\title{
Response of Millet and Sorghum to Water Stress in Converted Poorly Drained Paddy Soil
}

\author{
Ki-Yuol Jung*, Eul-Soo Yun, Chang-Young Park, Jae-Bok Hwang, Young-Dae Choi, and In-Seok Oh \\ Coarse Cereal Crop Research Division, NICS, RDA, Milyang, 627-830, Republic of Korea
}

(Received: October 26 2013, Accepted: November 6 2013)

\begin{abstract}
Millet and sorghum are major dryland cereal crops, however their growth and productivity is limited by soil water stress with varying intensity. The major objective of this study was to evaluate water stress of millet and sorghum yield under drainage classes of poorly drained soil and to test the effect of the installed pipe drainage in poorly drained paddy soil to minimize crop stress. The research was caried out in poorly drained paddy fields located at alluvial slopping area resulting in non-uniform water content distribution by the inflow of ground water from the upper part of the field. Stress Day Index (SDI) was determined from a stress day factor (SD) and a crop susceptibility factor (CS). SD is a degree of measurement by calculating the daily sum of excess water in the profile above $30 \mathrm{~cm}$ soil depth $\left(\mathrm{SEW}_{30}\right)$. $C S$ depends on a given excess water on crop stage. The results showed that sum of excess water day $\left(S W D_{30}\right)$ used to represent the moisture stress index was lower on somewhat poorly drained soil compared with poorly drained soil on 117 days. CS values for sorghum were $57 \%$ on $3^{\text {rd }}$ leaf stage, $44 \%$ on $5^{\text {th }}$ leaf stage, $37 \%$ on panicle initiation, $23 \%$ on boot stage, and $16 \%$ on soft dough stage. For proso millet CS values were $84 \%$ on $3^{\text {rd }}$ leaf stage, $70 \%$ on $5^{\text {th }}$ leaf Stage, $65 \%$ on panicle initiation, $53 \%$ on boot stage, and $28 \%$ on soft dough stage. And for foxtail millet the values were $73 \%$ on $3^{\text {rd }}$ leaf stage, $61 \%$ on $5^{\text {th }}$ leaf stage, $50 \%$ on panicle initiation, $29 \%$ on boot stage, and $15 \%$ on soft dough stage. SDI of sorghum and millet was more susceptible to excess soil water during panicle initation stage more poorly drained soil than somewhat poorly drained soil. Grain yield was reduced especially in proso millet and Foxtail millet compared to Sorghum.
\end{abstract}

Key words: Sorghum, Millet, Water stress, Crop susceptibility, Stress day index

Response of millet and sorghum to water stress under drainage classes in converted paddy soil.

\begin{tabular}{|c|c|c|c|c|c|c|}
\hline \multirow{2}{*}{ Growth Stage } & \multicolumn{2}{|c|}{ Duration } & \multirow{2}{*}{$\begin{array}{c}\mathrm{CS}^{\dagger} \\
\text { Factors }\end{array}$} & \multicolumn{3}{|c|}{$\overline{\mathrm{SDI}^{\ddagger}}$} \\
\hline & Start & Stop & & Sorghum & Proso millet & foxtail millet \\
\hline Emergence & 0 & 6 & 0.20 & 28.2 & 42.8 & 42.8 \\
\hline $3^{\text {rd }}$ Leaf Stage & 6 & 15 & 0.22 & 34.9 & 45.1 & 44.7 \\
\hline $5^{\text {th }}$ Leaf Stage & 15 & 28 & 0.32 & 47.3 & 71.3 & 78.6 \\
\hline Panicle Initation Stage & 28 & 47 & 0.19 & 11.6 & 31.8 & 49.4 \\
\hline Booting Stage & 47 & 61 & 0.08 & 11.4 & 7.4 & 7.4 \\
\hline Soft dough Stage & 61 & 75 & 0.02 & 3.7 & 4.4 & 2.9 \\
\hline
\end{tabular}

${ }^{\dagger} \mathrm{CS}=$ Crop susceptibility factor

${ }^{\dagger} \mathrm{SDI}=$ Stress-day Index 


\section{Introduction}

내건성 작물인 조, 수수, 기장 등의 잡곡류는 내습성이 매우 약한 특성을 갖고 있어 논에 재배할 경우 습해로 인한 생산량 감소가 우려되므로 안정적인 생산을 위해서는 내습 성 품종 선택, 특별한 수분관리기술이 반드시 필요하다. 배 수가 불량한 농경지에서는 토양수분이 과다하게 되면 토양 공극에 수분이 포화되어 작물에 산소공급이 부족하게 되고 토양환원에 의한 유해 물질의 발생 등으로 미생물의 활동이 제한되어 작물에 스트레스를 주게 된다고 알려져 있다 (Box, 1991; Cannell \& Jackson, 1981; Hiller, 1976; Plamenac, 1988, Wesseling, J. 1974;). Hiller (1969)는 토양의 배수가 불량하게 되면 토양 공극의 대부분이 수분으로 포화되게 되 어 미생물의 활동으로 산소가 부족하게 되고 황화수소 $\left(\mathrm{H}_{2} \mathrm{~S}\right)$ 와 같은 유해 가스가 발생하게 되며 작물뿌리의 생장을 저 해하게 되어 작물 생육과 수량에 영향을 미친다고 보고하였 다 (Box, 1991; Cannell \& Jackson, 1981). Kono et al. (1987) 은 주요 작물의 과습에 대한 평가를 통해 내습성 정도를 네 개의 등급으로 분류하였다. 내습에 가장 강한 작물은 밭벼 (Upland rice), 율무 (Job' tears) 이며, 두 번째로 손가락 조 (Finger millet), 피 (Japanese barnyard millet) 이였으며, 세 번째 등급은 기장 (Proso millet), 진주조 (Pear millet), 수수 (Sorghum) 등 이었고 가장 습해에 약한 작물은 조 (Foxtail millet), 옥수수 (Maize)등 이라고 보고하였다. 또 한 Kono et al. (1988)은 생육기간 중 인위적으로 장기간 과 습 조건을 처리하여 뿌리 형태를 평가한 결과 조는 전체 뿌 리의 수가 감소하며, 기장과 진주조는 약간 감소하고, 밭벼, 율무, 피, 수수, 옥수수 등은 뿌리의 수가 증가한다고 하였 다. 그리고 밭벼, 손가락 조, 율무, 피 등은 뿌리 분얼수가 증가하는 반면 수수, 옥수수 등은 분얼수가 변화하지 않는 다고 보고하였다. Hundal et al. (1984)은 수수의 경우 토양 과습에 대한 내성이 다른 잡곡에 비해 상대적으로 강한 편 이며 강우기에도 잘 견디는 작물이라고 보고하였다.

작물 생육기간 중 작물이 받는 수분과잉에 의한 수분 스 트레스 반응을 해석하기 위한 여러 가지 모델이 개발되어 왔으며, Hiler (1969)는 수분 스트레스 반응을 정량화하기
위해 지하수위의 누적일수기준으로 수분 스트레스 지표 (Stress-day Index, SDI)를 제안하였다. SDI는 SD (Stress day factor)와 CS (Crop susceptibility factor)를 이용하여 정량화 하였다. $\mathrm{SD}$ 는 토양 중에 수분과부족, 산소부족, 투 수력, 지하수위 등의 값을 극한치와 연관하여 얻어지며 주 로 과잉 토양수분으로 인하여 생기는 작물의 스트레스 정도 를 나타내는 기준값이다. Sieben (1964)이 제안한 대부분의 작물 수분스트레스 지표인 지하수위 $30 \mathrm{~cm}$ 를 초과한 일평 균 지하수위의 상승빈도 $\left(\mathrm{SEW}_{30}\right)$ 를 $\mathrm{SD}$ factor 값을 계산하 여 이용하였다. 또한 CS는 주요 생육기간 동안에 임계 스트 레스를 받은 작물의 수량을 조사하여 실험적으로 계산하였 다. Evans et al. (1991)은 옥수수와 콩을 대상으로 토양수 분 과잉에 의한 수분 스트레스 반응을 정량화 하여 6 년간 시험을 통해 Stress-day Index (SDI) 모델을 개발하였다. Jung et al. (1991)은 경사지 논토양에서 배수개선 방법에 에 따른 콩의 생육기간 중 수분 스트레스 지표 $(\mathrm{SDI})$ 를 분석한 결과 명거배수 355.40 , 비닐차단막 271.55 , 관다발 171.55 로 높 은 반면 암거배수에서는 64.75 로 크게 낮아진다고 밝혔다. Skaggs (1978)는 토양수분 과습에 의한 물 수지를 분석하고 배수개선 효과를 평가하기 위해 토양특성, 지하수위, 강우 량, 증발산량, 투수량, 표면 유거량, 보수력 등의 요인을 적용 한 물관리 모델 (DRAINMOD)을 개발하였으며, Hardjoamidjojo et al. (1982)은 과잉 토양수분 스트레스에 의한 작물의 수 량 예측모델을 개발하였다.

따라서 본 연구는 논에서 잡곡의 안정적인 생산기술을 개발하기 위해 품종별 내습성을 평가하고, 수분조건, 지하 수위, 재배양식 및 재배방법에 따른 스트레스 반응을 비교 분석 하였다.

\section{Materials and Methods}

시험토양의 특성 잡곡의 논 재배를 위한 내습성 평가 시험이 수행된 토양은 경남 창원시 북면 외산리에 소재한 경사 7 15\%의 곡간 상부에 위치하고 있으며 화강암에서 유 래된 산성암 충적층을 모재로 이루어진 토양이다. 미농무성 (USDA)의 새로운 분류방법에 의하면 식양계의 회색토로 지산통

Table 1. Physical properties of the research field soil before experiment.

\begin{tabular}{cccccccc}
\hline \multirow{2}{*}{ Horizon } & Depth & \multirow{2}{*}{ Bulk density } & \multicolumn{3}{c}{ Three phases } & Porosity & $\begin{array}{c}\text { Textural } \\
\text { Class }\end{array}$ \\
\cline { 4 - 5 } & & Mg m-3 & Solid & Water & Air & & \% \\
Ap1 & $0-10$ & 1.18 & 44.5 & 40.2 & 15.3 & 55.5 & loam \\
Ap2 & $10-20$ & 1.55 & 58.6 & 25.9 & 15.5 & 41.4 & loam \\
Ag & $20-24$ & 1.62 & 61.2 & 24.1 & 14.7 & 38.8 & loam \\
Bg & $24-35$ & 1.60 & 60.3 & 22.3 & 17.4 & 39.7 & Sandy loam \\
BCg & $35+$ & 1.60 & 60.4 & 25.0 & 14.6 & 39.6 & Sandy loam \\
\hline
\end{tabular}


(fine loamy, mixed, mesic family of Fluvaquentic Endoaquept) 에 해당된다. 주변이 산으로 둘러싸여 있어 연중 농경지 논 둑 아래에서 용출수가 유입되어 돈둑 밑은 연중 과습하고 논두렁 부분은 상대적으로 수분이 낮아 필지 내 수분상태가 불균일한 농경지 이었다. 표토 (Ap층)는 암회갈색 (2.5Y 4/2) 의 양토이고 심토1 (Bg층)은 회색 (5Y 5/1)의 식양토이며 심 토2 (BCg층)는 회색 (5Y 5/1)의 사양토로 이루어져 있다 (Table 1).

시험포장은 배수가 “매우불량”인 논 1개 필지, 배수등급 이 “약간불량”인 논 1 개 필지로 선정하였다. 시험포장은 토 양수분을 조절하기 위해 각 필지에 명거배수와 암거배수 시 설을 장변 방향으로 논둑 바로 밑에 1 열로 각각 설치하였다. 배수가 “매우불량”인 논은 폭 $30 \mathrm{~cm}$ 에 깊이 $30 \mathrm{~cm}$ 의 지표 명거배수로를 설치하였고, 배수등급이 “약간불량”인 논은 논 둑 밑 기저부에 폭 $50 \mathrm{~cm}$ 에 깊이는 상류부 $60 \mathrm{~cm}$, 하류 부 $90 \mathrm{~cm}$ 로 굴삭하고 $20 \mathrm{~cm}$ 직경의 유공흡수관을 매설하고 흡수거는 상류로부터 침출수를 최대한 흡수하기 위해 소수 재 (자갈층)를 논 면의 $15 \sim 20 \mathrm{~cm}$ 깊이까지 충전하여 암거 배수처리를 하였다.

시험구 배치 및 재배방법 시험구 배치는 배수가 "매 우불량”인 논과 “약간불량”인 논에서 단구제 2 반복으로 수 행하였으며, 시험작물은 수수 3 품종, 기장 3 품종, 조 3 품 종을 각각 공시하였으며, 논의 단면 방향으로 배치하였다. 수수는 황금찰수수, 토종수수, 중모 4001이었고, 기장은 황 금기장, 만홍기장, 노랑찰기장 이었으며, 조는 경관1호, 삼 다메조, 삼다차조 등을 공시하여 2010년부터 2011년까지 2 년간 수행하였다. 재배법은 농촌진흥청의 잡곡 표준재배법 에 준하여 재배하였으며, 생육 및 수량조사는 농촌진흥청 농업과학기술 연구조사분석기준 (농촌진흥청, 2012)에 준해 논의 단면 방향으로 $3 \mathrm{~m}, 6 \mathrm{~m}, 9 \mathrm{~m}, 12 \mathrm{~m}, 15 \mathrm{~m}$ 지점에서 3 반복으로 경장, 수장, 경태, 천립중, 주당립수, 주당협수, 수량 등을 조사하였다.

지하수위 및 토양수분 측정 배수방법별 지하수위의 실시간 변동을 측정하기 위해 논둑 밑에서 각각 $3 \mathrm{~m}, 10 \mathrm{~m}$, $15 \mathrm{~m}$ 지점에 깊이 $1.5 \mathrm{~m}$ 까지 측정할 수 있는 데이터로거가 장착된 수위측정기 (Ecotone TM WM)를 설치하고 1시간 단 위로 수위 변화를 조사하였다 (Fig. 3-1). 또한 토양 깊이별 토양수분은 배수개선지점에서 $3 \mathrm{~m}, 10 \mathrm{~m}, 15 \mathrm{~m}$ 지점에 각 각 Electrical Capacitance 방식의 층위별 수분측정센서 (Easy AG50-5Wire, Sentek Pty Ltd.)를 설치하여 토양 면에서 토 양의 깊이에 따라 $10 \mathrm{~cm}$ 단위로 0 50 $\mathrm{cm}$ 까지 1시간 간격 으로 파종기부터 수확기까지 잡곡 생육기간 동안 토양수분 을 측정하였다.
수분 스트레스 지표 배수방법별 지하수위를 기준으로 생육기간 중 작물이 받는 수분과잉에 의한 스트레스의 누적 일수를 정량화 하기위해 Hiler (1969)가 제안한 수분 스트레 스 지표 (Stress-day Index, SDI)를 적용하여 식(1)과 같이 분석하였다.

$$
S D I=\sum_{i=1}^{n} S D_{i} \times C S_{i}
$$

여기서, $\mathrm{SDI}$ : 수분 스트레스 지표

SDi : Stress day factor for stage i

CSi : Crop susceptibility factor for stage $i$

$\mathrm{n}$ : 생육기의 수

i : 생육시기

$\mathrm{SD}$ (Stress Day Factor)는 토양 중에 수분과부족, 산소부 족, 투수력, 지하수위 등의 값을 극한치와 연관하여 얻어진 값이다. Hardjoamidjojo et al. (1982)은 과잉 토양수분으로 인하여 생기는 작물의 스트레스 정도를 나타내는 기준값으 로 Sieben (1964)이 제안한 수분스트레스 지표인 지하수위 $30 \mathrm{~cm}$ 를 초과한 일평균 지하수위의 상승빈도 (SEW30)를 $\mathrm{SD}$ factor로 대신할 수 있다고 밝혀 식(2)과 같이 SD factor 값을 계산하였다.

$$
S E W_{30}=\sum_{i=1}^{n}\left(30-W T D_{i}\right)
$$

여기서, SEW30 : 지표 하 $30 \mathrm{~cm}$ 를 초과한 일평균 지하 수위의 상승빈도

WTDi : i 일의 일 지하수위의 깊이 $(\mathrm{cm})$

$\mathrm{n} \quad$ : 생육기간 일수

과잉수분의 초과일수 $\left(\mathrm{SED}_{30}\right)$ 는 식(3)과 같이 지하수위 깊이가 $30 \mathrm{~cm}$ 를 초과한 일평균 지하수위의 누적일수를 이 용하여 지하수위 변화를 분석하였다.

$$
S E D_{30}=\left(\sum \text { of Excess Water }-30 \mathrm{~cm}\right)
$$

작물의 주요 생육시기별 CS (Crop susceptibility factor) 를 산출하기 위해 과습처리 조건인 $\mathrm{W}-$ plot (water logged conditions)와 관행 처리조건 $\mathrm{M}$-plot (moderated soil moisture conditions)를 두어 시험하였다. W-plot 처리는플라스틱 $(1 / 5,000)$ 와그너포트에 $4 \mathrm{~kg}$ 의 토양을 채우고, 다시 $1 / 2,000$ 와그너 포트에 넣은 후에 $1 / 5,000$ 와그너포트 밑면의 급수구로부터 수분이 공급되어 토양표면 $10 \mathrm{~cm}$ 깊이까지 포화 되도록 처 
리하였다. 또한 W-plot의 과습처리는 3 엽기 ( $3^{\text {rd }}$ leaf stage), 5 엽기 ( $5^{\text {th }}$ leaf stage), 출아기 (Panicle initiation), 출수기 (Boot stage), 유숙기 (Soft dough stage)에 각 작물별로 10 일간 과습 조건이 되도록 처리하고 처리 후에는 $1 / 2,000$ 와 그너포트는 꺼내어 관행 처리조건 (M-plot)으로 재배하였다. CS (Crop susceptibility factor)는 수확기에 각 생육시기별 처리된 수량을 조사하여 Hiler (1969)가 제안한 각각 생육시 기에 대한 Crop susceptibility factor 산출수식(4)를 적용하 여 계산하였다.

$$
C S i=\frac{X-i}{X}
$$

여기서, $\mathrm{X}_{\mathrm{i}}: i$ 생육기에 임계 스트레스를 받은 작물의 수량 $\mathrm{X}$ : 아무런 스트레스를 받지 않은 경우의 작물 수량

\section{Results and Discussion}

토양 수분 변화 토양의 배수조건이 다른 “매우불량”인 논과 “약간불량”인 논에 배수시설을 시공하고 포장내 위치 에 따른 층위별 토양수분 측정 장치를 설치하여 잡곡 생육
기간 중 토양의 깊이에 따른 토양수분의 변화특성을 분석 하였다 (Table 2). 배수가 “매우불량”인 논에서 포장위치에 따른 평균 수분함량은 $30.61 \mathrm{~mm}$ 에서, $24.85 \mathrm{~mm}$ 로 높고 불 균일한 반면 배수가 “약간불량”인 논에서는 26.95 에서 22.15 $\mathrm{mm}$ 로 대체로 낮았으며 균일한 수분함량을 보였다. 토양수 분이 $30 \mathrm{~mm}$ day $^{-1}$ 을 초과한 토양수분 포화 누적시간은 "매 우불량”인 논에서 논둑 밑 지점 $1,934 \mathrm{hr}$ 에서 논두렁 지점 $1,934 \mathrm{hr}$ 인 반면 배수가 “약간불량” 인 논은 $1,493 \mathrm{hr}$ 에서 $836 \mathrm{hr}$ 으로 상대적으로 과습누적 지속시간이 낮았다. 또한 생육기간 중 토양수분이 $30 \mathrm{~mm} \mathrm{day}^{-1}$ 을 초과한 토양수분 포화 누적일수는 “매우불량”인 논에서 80일에서 54 일인 반 면 “약간불량”인 논은 62 일에서 37일로 상대적으로 과습누 적 일수가 짧게 나타났다. 따라서 “약간불량”인 논은 토양수 분포화 누적일수, 토양수분포화 지속시간, 생육기간 중 평 균 수분함량 등은 “매우불량”인 논에 비해 횔씬 낮은 경향을 보였다.

지하수위 변화 시험 포장의 배수조건에 따른 지하수 위 변화를 조사한 결과는 Fig. 1에서와 같았다. 생육기간 중 지하수위 변화는 배수 “매우불량” 논이 “약간불량” 논 보다 높았으며, 배수가 “매우불량”인 논에서 포장위치에 따른 평 균 지하수위는 논둑 밑이 $-14.90 \mathrm{~cm}$ 이고 논두렁 가까이에

Table 2. Comparison of soil water content in different drainage fields.

\begin{tabular}{ccccc}
\hline \hline Type of Drainage & Distance & Av. Soil water content & Duration time of excess water & Duration day of excess water \\
\hline \multirow{3}{*}{ Poorly drained } & & $\mathrm{mm}$ & $\mathrm{Hr}>30 \mathrm{~mm}$ & Day $>30 \mathrm{~mm}$ \\
& $1 \mathrm{~m}$ & 30.61 & 1,934 & 80 \\
& $5 \mathrm{~m}$ & 27.05 & 1,678 & 69 \\
& $10 \mathrm{~m}$ & 24.96 & 1,470 & 62 \\
Somewhat poorly & $15 \mathrm{~m}$ & 24.85 & 1,258 & 54 \\
drained & $1 \mathrm{~m}$ & 26.95 & 1,493 & 62 \\
& $5 \mathrm{~m}$ & 24.57 & 1,011 & 40 \\
& $10 \mathrm{~m}$ & 24.02 & 945 & 41 \\
\hline
\end{tabular}
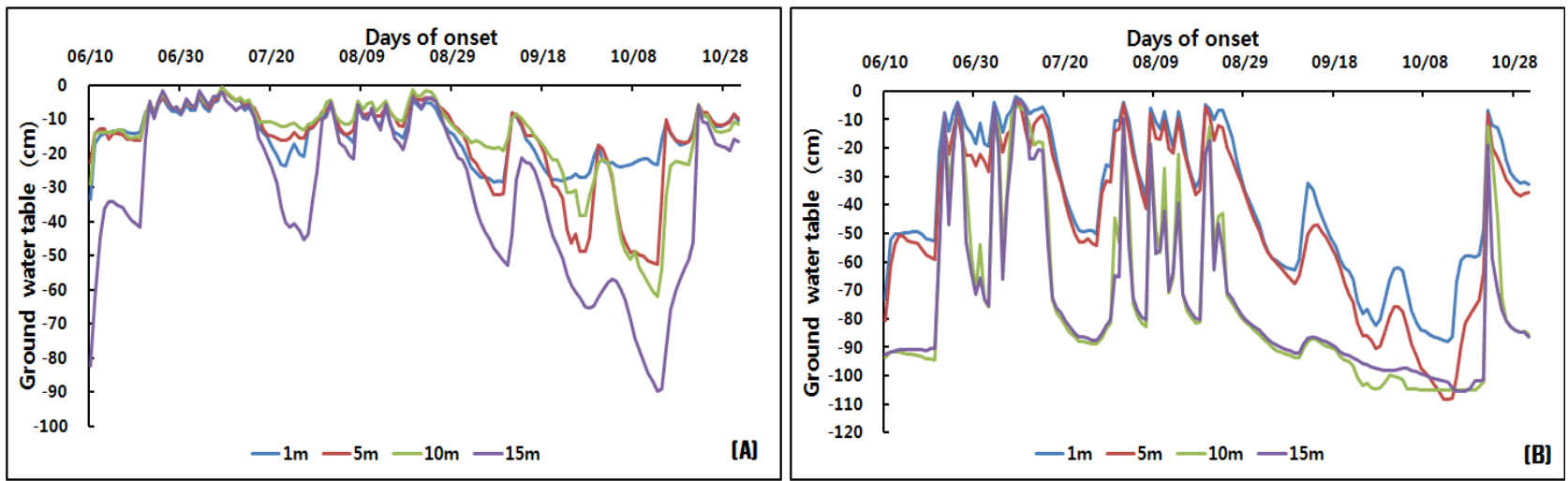

Fig. 1. Ground water level fluctuations in different drainage field. (A) Poorly drained. (B) Somewhat poorly drained. 
서는 $-30 \mathrm{~cm}$ 로 대체로 높고 불균일한 반면 배수가 "약간불 량”인 논에서는 $-38.45 \mathrm{~cm}$ 에서 $-74.19 \mathrm{~cm}$ 로 대체로 낮았으 며 균일한 지하수위를 보였다.

배수조건에 따른 지하수위를 기준으로 생육기간 중 잡곡 의 수분과잉에 의한 스트레스의 누적일수를 정량화하기 위 해 분석한 결과는 Table 3 에서와 같았다. 지하수위 $30 \mathrm{~cm}$ 를 초과한 일수의 합 $\left(\mathrm{SED}_{30}\right)$ 은 배수가 “매우불량”인 논에서는 포장위치에 따라 143 일에서 81일로 높은 반면 배수가 "약간 불량”인 논에서는 59 일에서 19 일로 대체로 낮은 경향을 보 였다. 또한 과잉수분에 의한 작물 스트레스 지표 (Stress day factor; SD)로 이용되는 지하수위 $30 \mathrm{~cm}$ 를 초과한 일평균 지하수위의 상승빈도 $\left(\mathrm{SEW}_{30}\right)$ 는 배수가 “매우불량”인 논에 서 2,178 $\mathrm{mm}$ 에서 $1,423 \mathrm{~mm}$ 로 조사 되었으며, “약간불량” 인 논에서는 $1,014 \mathrm{~mm}$ 에서 $221 \mathrm{~mm}$ 로 상대적으로 낮은 경향을 보였다. Sieben (1964)은 밭작물은 지하수위 $30 \mathrm{~cm}$ 초과수 위의 합 $\left(\mathrm{SEW}_{30}\right)$ 이 $1,000 \mathrm{~mm}$ 보다 크면 작물에 스트레스를 주어 수량감소를 가져오며, $1,000 \mathrm{~mm}$ 이내에 있으면 안전하
다고 하였다. 따라서 위의 $\mathrm{SEW}_{30}$ 기준으로 배수조건별로 스 트레스 지표를 비교하면 배수가 “매우불량”인 논에서는 밭작 물 안전기준을 초과하였으나 “약간불량”인 논에서는 지하수 위가 안전기준에 부합되어 습해에 안전한 것으로 나타났다.

주요 생육 시기별 수분 스트레스 반응 수수 (Sorghum bicolor L.)와 서속 (秋粟)류 잡곡인 조 (Setaria italica .L.) 와 기장 (Panicum miliaceum L.)의 주요 생육시기별 토양 과습처리에 따른 생육반응을 조사한 결과는 Fig. 2에서와 같았다. 과습처리 (W-plot)에 의한 수량 감소율은 생육초기 에 가장 낮았고 생육후기로 갈수록 수량 감소율이 높아지는 경향을 보였다. 또한 조와 기장이 수수에 비해 과습처리 (W-plot)에 의한 수량 감소율이 대체로 낮았고, 생육초기인 3 엽기에 수량 감소율은 조와 기장이 가장 크게 나타났다. 이러한 결과로 수수의 CS (Crop susceptibility factor)는 3 엽기 0.57, 5엽기 0.44, 유수형성기 0.37, 출수기 0.23, 유 숙기 0.16 이었고, 기장의 경우 3 엽기 $0.84,5$ 엽기 0.70 , 유

Table 3. Comparative values of water table in different drainage fields.

\begin{tabular}{|c|c|c|c|c|}
\hline Drainage & Distance & Av. Water table level & $\mathrm{SED}_{30}{ }^{\dagger}$ & $\mathrm{SEW}_{30}{ }^{\ddagger}$ \\
\hline \multirow{3}{*}{ Poorly drained } & & $\mathrm{cm}$ & day & $\mathrm{mm}$ \\
\hline & $1 \mathrm{~m}$ & -14.90 & 143 & 2,178 \\
\hline & $5 \mathrm{~m}$ & -16.52 & 121 & 2,228 \\
\hline \multirow{8}{*}{$\begin{array}{c}\text { Somewhat poorly } \\
\text { drained }\end{array}$} & $10 \mathrm{~m}$ & -15.63 & 126 & 2,340 \\
\hline & $15 \mathrm{~m}$ & -30.54 & 81 & 1,423 \\
\hline & Average & -15.68 & 130.00 & $2,248.67$ \\
\hline & $1 \mathrm{~m}$ & -38.45 & 59 & 1,014 \\
\hline & $5 \mathrm{~m}$ & -45.40 & 53 & 710 \\
\hline & $10 \mathrm{~m}$ & -73.65 & 22 & 347 \\
\hline & $15 \mathrm{~m}$ & -74.19 & 19 & 221 \\
\hline & Average & -43.30 & 66.00 & $1,079.92$ \\
\hline
\end{tabular}

${ }^{\dagger} S E D_{30}=\left(\sum\right.$ of Excess Water $\left.-30 \mathrm{~cm}\right)$

${ }^{\ddagger} S E W_{30}\left(\sum\right.$ of Excess Water Depth $)=\sum_{i=1}^{n}\left(30-W T D_{i}\right)$
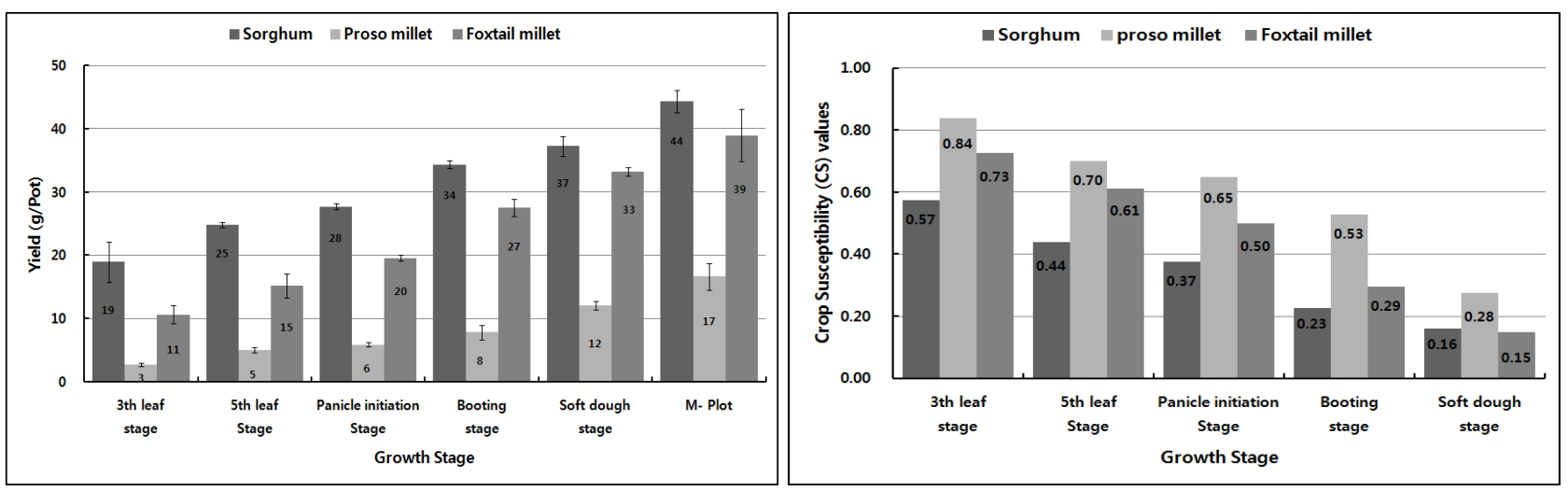

Fig. 2. Comparison of crop susceptibility of cereals crop growth stage by excessive water stress. 
수형성기 0.65 , 출수기 0.53 , 유숙기 0.28 이였으며, 조는 3 엽기 $0.73,5$ 엽기 0.61 , 유수형성기 0.50 출수기 0.29 , 유숙 기 0.15 이였다.

수분 스트레스 반응 조, 수수, 기장 등 잡곡의 논 재 배 시 배수조건에 따른 수분 스트레스 지표 $(\mathrm{SDI})$ 를 분석한 결과는 Table 4에서와 같았다. 배수가 “매우불량”인 논에서 생육단계별 수수가 받는 SDI는 출아기 28.2에서 유숙기 3.7 로 나타났으나, 기장은 출아기 42.8 에서 유숙기 4.4로 나타 났으며, 조는 출아기 42.8에서 유숙기 2.9로 수수에 비해서 조와 기장이 스트레스 지수가 높아 과습에 의한 영향을 가 장 많이 받은 것으로 나타났다. 또한 출아기와 유묘기, 3 엽 기 등 주로 생육초기의 SDI가 높았으며 생육후기로 갈수록 낮아지는 경향을 보였다. 배수가 “약간불량”인 논에서 수수 가 받는 $\mathrm{SDI}$ 는 출아기 3.4 에서 출수기 0.1 로 나타났으나,
기장은 출아기 10.5 에서 출수기 0.3 로 나타났으며, 조는 출 아기 10.5에서 유숙기 0.1로 상대적으로 배수가 "약간불량" 인 논에서 보다 “매우불량”인 논에서 수분 스트레스 지표 (SDI) 높은 경향을 보였다. 이러한 결과는 Kono et al. (1987) 이 주요 작물의 내습성 평가를 통해 조와 기장이 습해에 약 하다는 보고와 유사하였다.

잡곡의 논 재배 시 배수조건별 전 생육기간 동안 포장의 위치에 따른 수분 스트레스 지표 (SDI)를 분석한 결과는 Fig. 3 에서와 같았다. 수수의 경우 배수가 “매우불량”인 논의 논 둑 밑 $1 \mathrm{~m}$ 지점에서는 367.4 이었으나 $15 \mathrm{~m}$ 지점에서는 245 로 나타난 반면 “약간불량”인 논에서는 각각 197 과 53으로 크게 낮아지는 경향을 보여 “매우불량”인 논보다 낮았다. 기 장의 경우 “매우불량”인 논에서는 논둑 밑에서 거리별 SDI 가 각각 $310,292,269,196$ 으로 나타나 논의 중간 지점까지 수분과습에 의한 스트레스를 받는 것으로 나타났다. 또한

Table 4. Response of millets and sorghum to excess water stress under drainage classes.

\begin{tabular}{|c|c|c|c|c|c|c|}
\hline \multirow{2}{*}{ Growth Stage $^{\dagger}$} & \multicolumn{2}{|c|}{ Duration } & \multirow{2}{*}{$\begin{array}{c}\mathrm{CS}^{\ddagger} \\
\text { Factors }\end{array}$} & \multicolumn{3}{|c|}{$\mathrm{SDI}^{\phi}$} \\
\hline & Start & Stop & & Sorghum & Proso millet & foxtail millet \\
\hline \multicolumn{7}{|l|}{ Poorly drained } \\
\hline Emergence & 0 & 6 & 0.20 & 28.2 & 42.8 & 42.8 \\
\hline $3^{\text {rd }}$ Leaf Stage & 6 & 15 & 0.22 & 34.9 & 45.1 & 44.7 \\
\hline $5^{\text {th }}$ Leaf Stage & 15 & 28 & 0.32 & 47.3 & 71.3 & 78.6 \\
\hline Panicle Initation Stage & 28 & 47 & 0.19 & 11.6 & 31.8 & 49.4 \\
\hline Booting Stage & 47 & 61 & 0.08 & 11.4 & 7.4 & 7.4 \\
\hline Soft dough Stage & 61 & 75 & 0.02 & 3.7 & 4.4 & 2.9 \\
\hline \multicolumn{7}{|l|}{ Somewhat poorly drained } \\
\hline Emergence & 0 & 6 & 0.20 & 3.4 & 10.5 & 10.5 \\
\hline $3^{\text {rd }}$ Leaf Stage & 6 & 15 & 0.22 & 5.2 & 12.4 & 11.9 \\
\hline $5^{\text {th }}$ Leaf Stage & 15 & 28 & 0.32 & 1.1 & 5.2 & 4.7 \\
\hline Panicle Initation Stage & 28 & 47 & 0.19 & 0.9 & 0.3 & 1.6 \\
\hline Booting Stage & 47 & 61 & 0.08 & 0.1 & 0.3 & 0.2 \\
\hline Soft dough Stage & 61 & 75 & 0.02 & - & - & 0.1 \\
\hline
\end{tabular}

${ }^{\dagger}$ Stage $=$ Refers to stage of sorghum development described by Vanderlip. (1979).

${ }^{\ddagger} \mathrm{CS}=$ Crop susceptibility factor

${ }^{\oint}$ SDI $=$ Stress-day Index
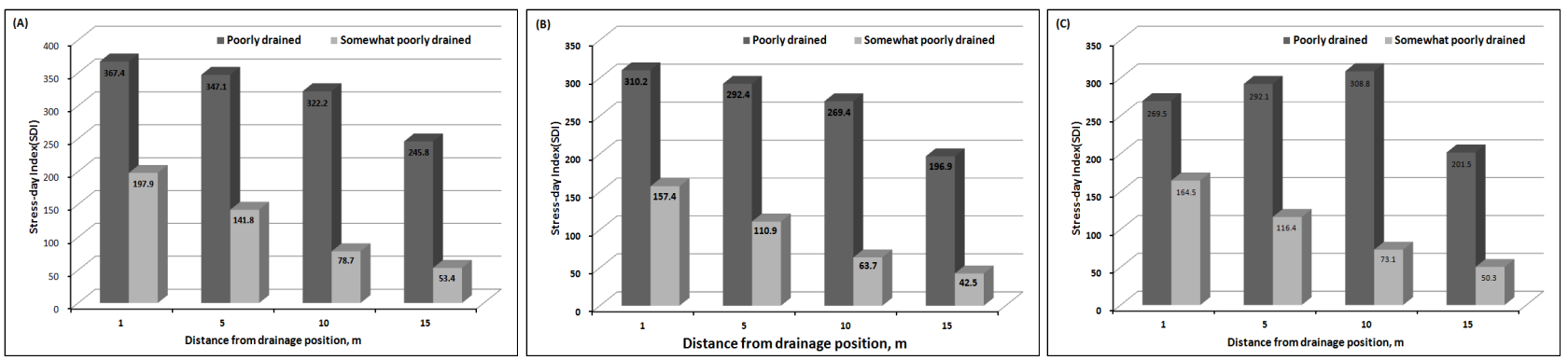

Fig. 3. Response to excess water stress as distance at installed drainage position under drainage classes; (A)sorghum, (B)proso millet(C)Foxtail millet. 
조도 기장과 유사한 결과를 보여 상대적으로 조와 기장은 습해에 약한 것으로 나타났다.

\section{토양수분 조건에 따른 잡곡의 생육반응 배수조건별} 포장위치에 따른 조, 수수, 기장의 생육반응을 조사한 결과 는 Fig. 4에서와 같았다. 생육기간 중 과습에 의한 생육장해 는 간장에 가장 영향을 미치는 것으로 나타났다. 포장의 위 치에 다른 간장의 변화는 배수 “매우불량”인 논이 "약간불 량”인 논에 비해 변이가 크게 나타났으며, 수수는 포장의 위 치에 따라 품종 간에 간장이 거의 균일한 반면, 조와 기장은 습해에 약해 대체로 차이가 크게 나타났으며, 조가 기장에 비해 과습에 영향을 많이 받는 것으로 보였다. 특히 배수
“매우불량”인 논에서 기장의 경우 노랑찰기장이 만홍기장과 황금기장에 비해 습해에 강하였으며, 조는 경관1호, 삼다 메, 삼다찰 순으로 품종 간에 뚜렷한 차이를 보였다. 특히, 삼다메와 삼다찰의 경우 논둑 밑에서는 과습에 의해 습해를 받아 생육초기에 고사되었다.

배수조건별 포장위치에 따른 조, 수수, 기장의 수량반응 을 조사한 결과는 Fig. 5에서와 같았다. 배수 “매우불량”인 논이 “약간불량”인 논에 비해 배수조건에 따라 수량변화의 차이가 크게 나타났다. 수수는 조와 기장에 비해 포장의 위 치에 따라 수량의 변이가 낮았으며, 조와 기장은 수수에 비 해 배수조건과 포장의 위치에 따라 수량의 변이가 크게 나 타났다. 수수의 경우 토종수수와 황금찰수수가 습해에 강하
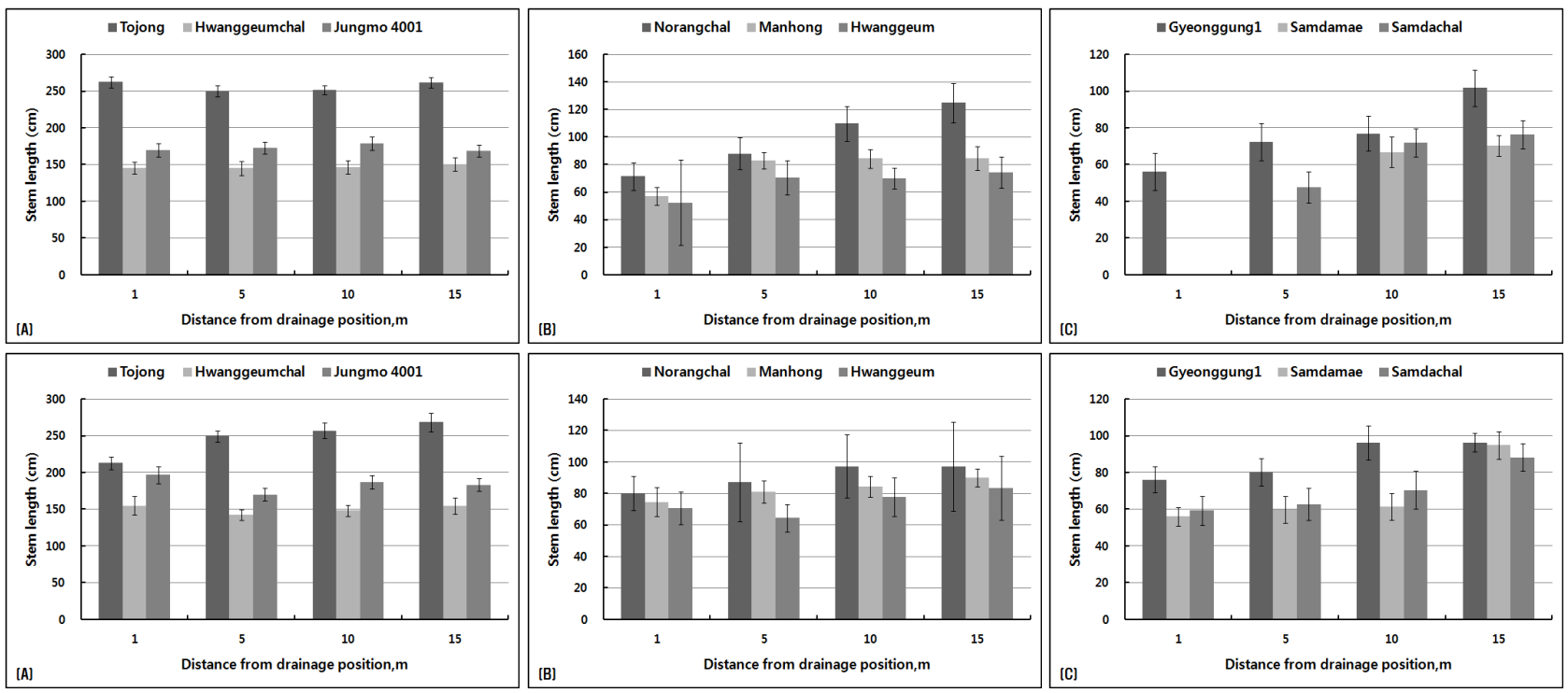

Fig. 4. Comparison of sorghum, proso millet and foxtail millet stem length as distance at installed drainage position under drainage classes. Upper: Poorly drained field, Under : Somewhat poorly drained field; (A)sorghum, (B)proso millet, (C)Foxtail millet.
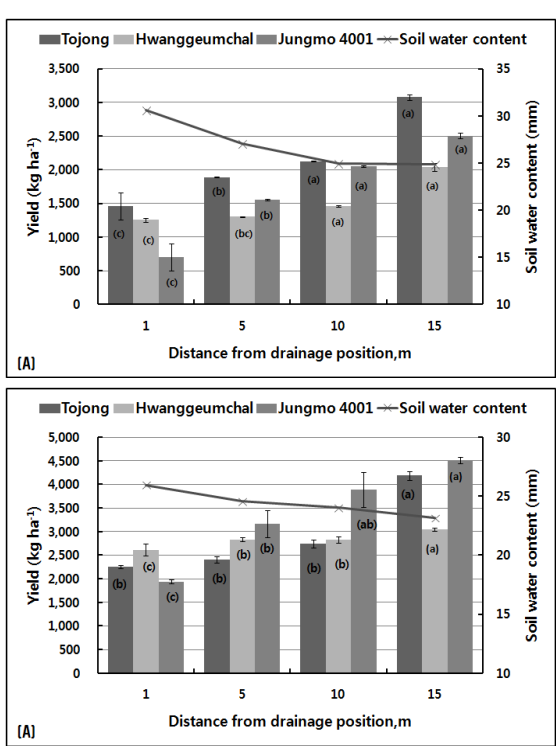

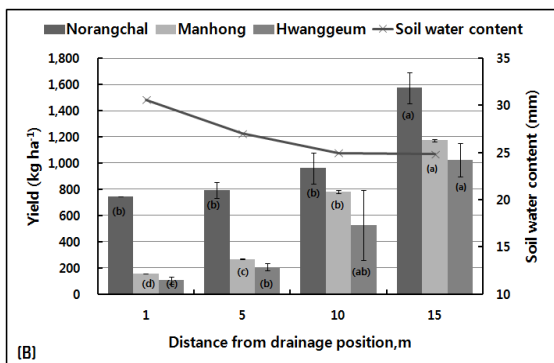

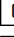

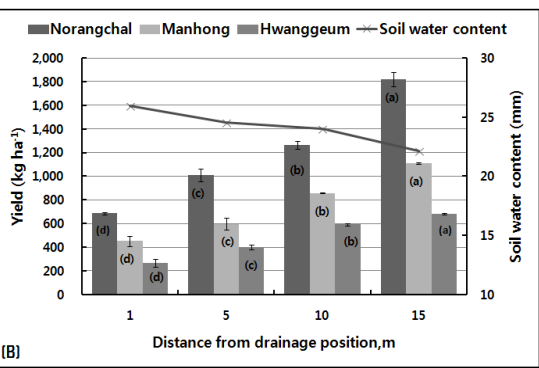

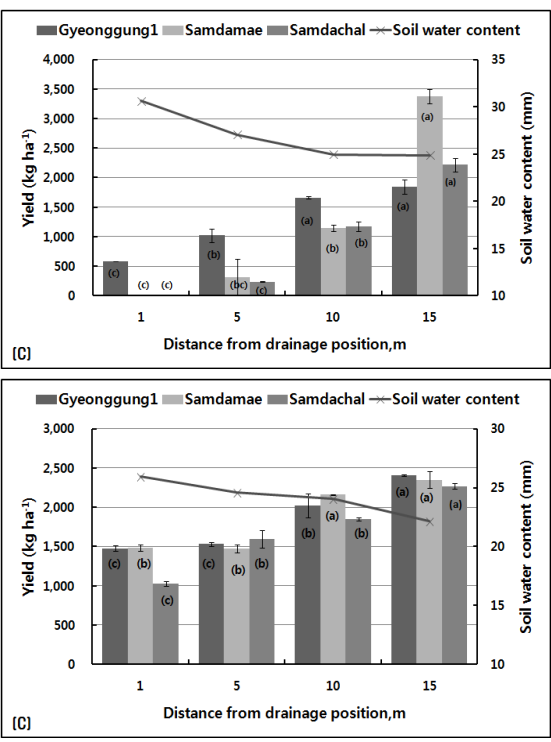

Fig. 5. Comparison of sorghum, proso millet and foxtail millet yield as distance at installed drainage position under drainage classes. Upper: Poorly drained field, Under : Somewhat poorly drained field; (A)sorghum, (B)proso millet, (C)Foxtail millet. 
였으나 중모 4001은 습해에 약한 것으로 나타났다. 기장은 노랑찰기장, 만홍기장, 황금기장 순으로 습해에 약해 수량 이 낮았으며, 조는 경관 1호, 삼다메, 삼다찰 순으로 수량이 낮았다. 이러한 결과는 Hundal et al. (1984)이 수수의 경우 토양 과습에 대한 내습성이 다른 잡곡에 비해 상대적으로 강한 편이며 강우기에도 잘 견디는 작물이라고 보고한 내용 과 유사하였다. 따라서 논에서는 수수가 조와 기장에 비해 습해에 강한 작물임을 알 수 있었다.

\section{Conclusions}

수수 (Sorghum bicolor L.)와 서속 (黍栗)류 잡곡인 조 (Setaria italica .L.)와 기장 (Panicum miliaceum L.)의 논 재배시 안정적인 생산기술을 개발하기 위해 품종별 내습성 을 평가하고, 수분조건, 지하수위, 재배양식 및 재배방법에 따른 수분과잉에 의한 스트레스 반응을 비교 분석한 결과 다음과 같은 결론을 얻었다.

배수조건에 따른 지하수위를 기준으로 생육기간 중 지하 수위 $30 \mathrm{~cm}$ 를 초과한 일수의 합 $\left(\mathrm{SED}_{30}\right)$ 은 배수가 "매우불 량”인 논에서는 포장위치에 따라 143 일에서 81 일로 높은 반 면 배수가 “약간불량”인 논에서는 59일에서 19일로 대체로 낮은 경향을 보였다. 또한 과잉수분에 의한 작물 스트레스 지표 (Stress day factor; SD)로 이용되는 지하수위 $30 \mathrm{~cm}$ 를 초과한 일평균 지하수위의 상승빈도 $\left(\mathrm{SEW}_{30}\right)$ 는 배수가 “매우불량”인 논에서 $2,178 \mathrm{~mm}$ 에서 $1,423 \mathrm{~mm}$ 로 조사 되었 으며, "약간불량”인 논에서는 $1,014 \mathrm{~mm}$ 에서 $221 \mathrm{~mm}$ 로 상대 적으로 낮은 경향을 보였다.

주요 생육 시기별 잡곡의 수분 스트레스 반응은 (Crop susceptibility factor)은 수수의 수수의 경우 3 엽기 $0.57,5$ 엽기 0.44 , 유수형성기 0.37 , 출수기 0.23 , 유숙기 0.16 이 었고, 기장의 경우 3 엽기 $0.84,5$ 엽기 0.70 , 유수형성기 0.65 , 출수기 0.53 , 유숙기 0.28 이였으며, 조는 3 엽기 $0.73,5$ 엽 기 0.61 , 유수형성기 0.50 출수기 0.29 , 유숙기 0.15 이였 다. 조, 수수, 기장 등 잡곡의 논 재배시 배수조건에 따른 수분 스트레스 지표 $(\mathrm{SDI})$ 는 배수가 “매우불량”인 논에서 수 수는 출아기 28.2에서 유숙기 3.7로 나타났으나, 기장은 출 아기 42.8 에서 유숙기 4.4 로 나타났으며, 조는 출아기 42.8 에서 유숙기 2.9로 수수에 비해서 조와 기장이 스트레스 지 수가 높아 과습에 의한 영향을 가장 많이 받았다.

배수조건별 포장위치에 따른 조, 수수, 기장의 수량반응 을 조사한 결과 수수는 조와 기장에 비해 포장의 위치에 따 라 수량의 변이가 낮았으며, 조와 기장은 수수에 비해 배수 조건과 포장의 위치에 따라 수량의 변이가 크게 나타났다. 따라서 잡곡의 논 재배시 수수가 조와 기장에 비해 습해 에 강한 작물이었으며, 수수는 토종수수와 황금찰수수가 습
해에 강하였으나 중모 4001 은 습해에 약한 것으로 나타났 고, 기장은 노랑찰기장, 만홍, 황금기장 순으로 습해에 약해 수량이 낮았으며, 조는 경관 1호, 삼다메, 삼다찰 순으로 습 해에 약한 품종으로 나타났다.

\section{References}

Box, J.E.Jr. 1991. The effect of waterloogging on rooting intermittent flooding on germination and seeding growth of cotton. Trans. ASAE. 14:567-570.

Cannell, R.Q. and M.B. Jackson. 1981. Alleviating aeration stress. p. 141-192. In G.f. Arkin and H.M. Talors (ed) Modifying the root environment to reduce crop stress. ASAE. St.Joseph. MI.

Evans, R.O., R.W. Skaggs, and R.E. Sneed. 1991. Stress say index models to predict corn and Soybean relative yield under high water table condition. Trans. ASAE. 34:1997-2005.

Jung, K.Y., E.S. Yun, C.Y. Park, J.B. Hwang, Y.D. Choi, and K.D. Park. 2011. Stress day index to predict soybean yield response by subsurface drainage in poorly drained sloping paddy fields. Korean J. Soil Sci. Fert. 44(5):702-708.

Hardjoamidjojo. S. and R.W Skaggs. 1982. Predicting the effects of drainage systems on corn yields. Agricultural Water Management. 5(2):127-144.

Hiler, E.A. 1969. Quantitative evaluation of crop drainage requirements. Trans. ASAE. 12:499-805.

Hiler, E.A. 1976. Drainage requirements of crops Proc. ASEA, Third national Drainage Symposium. ASAE. p. 127-129.

Hundal, S.S., and S.K. De Datta. 1984 Water table and tillage effect on root distribution, soil water extration, yield of sorghum grown after wetland rice in a tropical soil. Field Crops Research. 9:291-303.

Kono, Y., A. Yamauchi, N. Kawamura, J. Tatsumi, T. Nonoyama, and N. Inagaki. 1987. Interspecific difference of the capacities of waterlogging and drought tolerance among summer cereals. Japan. Jour. Crop Sci. 56(1):115-129.

Kono, Y., A. Yamauchi, N. Kawamura, T. Nonoyama, and J. Tatsumi. 1988. Comparison of Growth responses to waterlogging of summer cereals with special reference to rooting ability. Japan. Jour. Crop Sci. 57(2):321-331.

Plamenac, N. 1988. Effects of subsurface drainage on heavy hydromorphic soil in the Nelindvor area, Yugoslavia. AWM. 14:19-27.

Sieben, W.H. 1964. Relation of drainage conditions and crop yields on young light clay soils in the yssellake polders. Van Zee tot Land, No. 40.

Skaggs, R.W. 1978. A water management model for shallow water table soils, Rep. No. 134, Water Resour. Res. Inst. Univ. North Carolina. p. 178.

Wesseling, J. 1974. Crop growth and wet soils. p. 39-90. In J. van Schitfgaard (Ed) Drainage for Agriculture. Agron. Monogr. 17.ASA. Madison. WI. 